\title{
Lean manufacturing as a tool for increasing labor productivity at the enterprise
}

\author{
$N$. Ketoeva $^{1}, N$. Soldatova ${ }^{1}$, and $S$. Ilyashenko ${ }^{2, *}$ \\ ${ }^{1}$ National Research University "Moscow Power Engineering Institute", Moscow, Russia \\ ${ }^{2}$ Plekhanov Russian University of Economics, Moscow, Russia
}

\begin{abstract}
Since the beginning of utilization of the lean production concept it has passed several stages of implementation. The first stage failed because manufacturers that introduced lean production methods were isolated from each other; whereas in the second stage, these companies learned from their experiences. Since then, the lean production concept has been used to organize production and reduce costs, despite the fact that markets are becoming more demanding due to individualization of demand and variability of conditions. Digitalization suggests methods for adapting the concept of lean production to such a market indicator as company performance. Thus, the utilization of the concept "Industry 4.0" can initiate the third stage of development of the practice of lean manufacturing in terms of analyzing the productivity from a multidimensional point of view.
\end{abstract}

\section{Introduction}

The fourth industrial revolution and its Industry 4.0 or connected industry technologies dominates the current discussion of production research [1, p. 125].

Lean manufacturing (LM) has proven its positive effects on operational and economic performance in multiple cases. However, growing consciousness regarding sustainability and the Triple Bottom Line approach requires an integral performance based on three main goals: economic growth, environmental preservation, and social responsibility [2, p.99]

Many companies allocate significant resources to implement lean at the manufacturing shop floor, but fewer resources to implement lean at the product development processes [3, p.301].

Over the last 30 years, competitive pressures in the business environment have focused attention on organisational efficiency popularising management theories such as LM [4, p.260].

The Russian companies, which implement lean manufacturing management, can gain the maximum outcome from automation and digitalization of production processes considering them a management solution in response for growing remuneration demands from employees, given a high proportion of labor in the production process.

The article provides an overview of the most relevant research results in this area in order to identify the modern aspects of lean production (LP) influence on the sustainable performance of the Russian companies.

The purpose of this study is to solve two groups of problems: assessment of the impact of lean production management on enterprise productivity and definition of a multidimensional point of view about sustainable productivity.

During the work, the following tasks were solved:

- Search for statistical data, their processing and correct interpretation for the subsequent analysis of the impact of lean production on the sustainable performance of the company;

- Evaluation of various approaches and tool sets of lean manufacturing, which affect productivity, mainly from an operational or economic point of view.

The instrumental and methodological apparatus is based on general scientific methods: induction, deduction and elements of a system analysis of the processes of sociology development in the field of electric power industry, based on quantitative and qualitative research methods. In addition, methods of logical, statistical and situational analysis are used.

The information and empirical base of the research consists of the authors' previous works on this theme [5, 6].

\section{Literature review}

Manufacturing companies are forced to act in an economical manner as these market conditions are steadily intensifying towards the future [7, p.198].

Lean Production (LP) is one of the most common initiatives in Operations Management that firms adopt to boost their competitiveness [8, p.83].

Lean manufacturing brings about incremental change relying on administrative, process and routine levers. It best fits mass production where process variability is low and demand is high and stable [9].

\footnotetext{
*Corresponding author: svetavol@yandex.ru
} 
Table 1. Consumption of electrical energy in the Russian Federation for 2009-2017.

\begin{tabular}{|l|c|c|c|c|c|c|c|c|c|}
\hline Year & 2009 & 2010 & 2011 & 2012 & 2013 & 2014 & 2015 & 2016 & 2017 \\
\hline bln kW & 977.1 & 1020.6 & 1041.1 & 1063.3 & 1054.8 & 1065.0 & 1060.2 & 1077.7 & 1089.1 \\
\hline
\end{tabular}

Table 2. Electricity generation in the Russian Federation for 2009-2017.

\begin{tabular}{|l|c|c|c|c|c|c|c|}
\hline Year & 2009 & 2010 & 2012 & 2013 & 2014 & 2015 & 2017 \\
\hline bln kW & 991.9 & 1038.0 & 1069.2 & 1059.9 & 1064.2 & 1067.5 & 1094.3 \\
\hline
\end{tabular}

Industry 4.0 is considered a new industrial stage in which vertical and horizontal manufacturing processes integration and product connectivity can help companies to achieve higher industrial performance [10, p.383].

Industry 4.0 has been considered a new industrial stage in which several emerging technologies are converging to provide digital solutions. However, there is a lack of understanding of how companies implement these technologies [11, p. 15].

The association between Industry 4.0 and LP has been increasingly highlighted in operations management research $[12,13]$. Over the past few years, researchers and practitioners have started to investigate how both approaches, when implemented together within companies, can raise operational and financial performances to a significantly higher level [12, p.3963].

Although lean production is widely deemed as a means for influencing the complexity of socio-technical systems, empirical evaluations of this impact have not adopted an explicit complexity theory perspective, nor have they accounted for the multidimensional nature of complexity [8, p.83].

The extended algorithm for investigation the impact of lean manufacturing on the sustainable productivity of Russian companies, which is a part of the general research methodology, includes the following sequence of actions:

1. Determination of the information and empirical base of research and influence the time intervals for the practices of applying the set of LP tools on the relationship between the degree of LP implementation and the obtained specific performance indicators of the company.

2. Classification of the degree of relationship between LP and sustainable productivity.

3. Survey on Russian practices of LP tools usage and effects from operating activities.

At the same time, the proposed algorithm has a number of limitations when analyzing the Russian experience, i.e. investigation of Russian companies operating in the energy market. The authors identified various approaches to the practice of using LP tools for the activities of Russian energy companies. On the other hand, identifying such approaches for the entire Russian industry seems almost impossible due to the large amount of data.

\section{Materials and methods}

In modern conditions, enterprises of the Russian energy sector are in a situation of rapid growth of competition, on the one hand, and increased state regulation, on the other hand (especially in the matter of limiting the tariff growth rates). Another factor that has a significant impact on the activities of energy sector enterprises is the annually increasing rates of energy consumption, in particular electricity (Table 1).

So, according to Rosstat, the amount of electricity consumed in Russia as a whole in 2017 was 1089.1 bln $\mathrm{kW}$, which is $1.1 \%$ more than a year earlier. On average, over the past incomplete decade, electricity consumption has increased by almost $12 \%$ (from 977.11 to $1089.1 \mathrm{bln}$ $\mathrm{kW})$.

Electricity generation also shows a positive growth trend (Table 2).

Electricity generation in Russia in 2017 amounted to 1094.3 billion $\mathrm{kW}$, which is $2.5 \%$ more than that in 2016. It should be noted that for the considered period, the volume of produced electricity increased only by $10.3 \%$. This ratio indicates the emergence of new consumers and industries.

Also, the trends in the energy sector include a change in the structure of electricity generation channels: a decrease in the share of thermal power plants and an increase in electricity generation at nuclear power plants.

In today's globalized market, where consumer power is extremely high, consumers often set their own ethical norms and rules for business, but prices are determined by the market. If the company copes with this situation, then it can increase its competitiveness. For the implementation of strategic objectives it is necessary to deploy several strategies.

The trends and structural changes that determine the architecture of world energy markets, as well as the development of new technologies as a factor of transformation of the institutional structure of markets cannot be disregarded [14, p.43]. 
Table 3. Influence of lean production

\begin{tabular}{|c|l|c|c|c|}
\hline No. & \multicolumn{1}{|c|}{ Influence of lean production } & \multicolumn{1}{|c|}{ Effect of performance } \\
\cline { 3 - 4 } & \multicolumn{1}{|c|}{ EE } & SE & EnE \\
\hline 1. & Cost reduction with parallel improving the process chain & $\mathrm{X}$ \\
\hline 2. & $\begin{array}{l}\text { Reduction of time to identify the problem, reduction of the non- } \\
\text { optimal material stocks }\end{array}$ & $\mathrm{X}$ & \\
\hline 3. & Safe and healthy work environment & & $\mathrm{X}$ & $\mathrm{X}$ \\
\hline 4. & Bringing the equipment into operation condition & $\mathrm{X}$ & \\
\hline 5. & Ability to carry out multiple orders simultaneously & $\mathrm{X}$ & \\
\hline 6. & $\begin{array}{l}\text { Balanced state of the staff load due to the formation of a global } \\
\text { vision of the process }\end{array}$ & $\mathrm{X}$ & $\mathrm{X}$ & \\
\hline 7. & Control of faults and defects & $\mathrm{X}$ & $\mathrm{X}$ & \\
\hline 8. & $\begin{array}{l}\text { Achievement of perfect production without breakdowns, stops, } \\
\text { failure and accidents (TPM) }\end{array}$ & $\mathrm{X}$ & $\mathrm{X}$ & \\
\hline 9. & $\begin{array}{l}\text { Partnership with suppliers (improvement of the quality of supplied } \\
\text { resources, control of incoming quality) }\end{array}$ & $\mathrm{X}$ & $\mathrm{X}$ & \\
\hline 10. & $\begin{array}{l}\text { DFMA- Management of the processes of the technical preparation of } \\
\text { production (design for assembly)/(design for manufacture) }\end{array}$ & $\mathrm{X}$ & $\mathrm{X}$ & \\
\hline
\end{tabular}

\section{Results}

Firms that espouse LP benefit from many advantages (manufacturing costs, productivity, inventory turnover, lead time, on-time delivery, fast delivery, flexibility, quality, space requirement, etc.). In fact, studies of LP have traditionally been associated with an analysis of its impact on operational performance [8, p.83].

There are many empirical data linking the use of LP tools and economic indicators of company performance that combine not only traditional indicators, such as profit, profitability indicators (profitability of the wage bill) or the level of the wage bill, but also social aspects (psychological stability of employees, lack of emotional burnout at work etc.).

Figure 1 presents the main stages of the formation of lean production concept.

\begin{tabular}{|c|c|}
\hline $\begin{array}{c}\text { Economical } \\
\text { efficiency }\end{array} \longrightarrow \begin{array}{c}\text { Environmental } \\
\text { efficiency }\end{array} \longrightarrow \begin{array}{c}\text { Social } \\
\text { efficiency }\end{array}$ \\
\hline
\end{tabular}

Fig.1. Main stages of formation of efficiency of lean production concept.

Economic efficiency (EE) can be calculated, in particular, using the following indicators: obtaining additional income, costs reduction, increasing production volumes associated with productivity growth.

An important element of environmental efficiency (EnE) is the assessment of the company's environmental policy, which takes into account the state of the environment, legislative and other requirements and restrictions, as well as the level of the enterprise responsibility in the field of environmental protection.

Social efficiency (SE) in the lean production model is achieved by constant improving the working climate, increasing employee satisfaction with their workplace and working conditions.

The obtained results are summarized in Table. 3 .

\section{Discussion}

Today's business conditions are characterized by increased competition. Therefore, enterprises have to cope with shorter product life cycles, higher product complexity and more product variants. The reaction of many enterprises is to implement lean production systems [15, p. 607].

Russian energy companies, which use lean production management, consider the LP system as a preliminary production strategy aimed at increasing the company productivity, improving product (service) quality and cost reduction. However, the pressure from the society is growing, and there appears a strong demand that the constant striving for efficiency and competitiveness of the company does not worsen the social conditions of the workers, wages and does not harm the environment.

The greatest impact from the use of lean production will be received by consumers, as in this case the reliability and quality of energy supply will increase. In addition, there is a potential to reduce the tariff load by optimizing the need for capital investments.

\section{Conclusions}

The following results were obtained while conducting this research. Lean production requires a change in organizational culture and a transition from authoritarian, profit-oriented management to humanistic management oriented at people development.

The company can use the funds received from cost reduction to modernize production processes, develop and introduce new technologies, which ultimately will increase its competitiveness and ensure sustainable development.

From this point of view, the introduction of the concept of lean production is not whatever associated with the type of the manufactured products and therefore 
it is applicable in the energy sector to the same extent as in any other industry.

\section{References}

[1] T. Wagner, C. Herrmann, S. Thiede, Industry 4.0 Impacts on Lean Production Systems. 63, 125-131 (2017)

[2] R. Henao, W. Sarache, I. Gómez, Lean manufacturing and sustainable performance: Trends and future challenges. 208, 99-116 (2019)

[3] G. Marodin, A.G. Frank, G.L. Tortorella, T. Netland, Lean product development and lean manufacturing: Testing moderation effects. 203, 301-310 (2018)

[4] A. Sartal, J. Llach, X.H. Vázquez, R. de Castro, How much does Lean Manufacturing need environmental and information technologies?, 45, 260272 (2017)

[5] E.E. Gudkova, G.N. Kurdukova, N.L. Ketoeva, The role of the University in the formation of an innovative environment. 2-2 (79-2), 671-674 (2017)

[6] N.F. Soldatova, Energy sector: some results of development. Economics and management in mechanical engineering. 6, 26-27 (2015)

[7] G. Hoellthaler, et al, Requirements for a methodology for the assessment and selection of technologies of digitalization for lean production systems. 79, 198 - 203 (2019)

[8] R. Abreu-Ledón, D.E. Luján-García, P. Garrido-Vega, B. Escobar-Pérez, A meta-analytic study of the impact of Lean Production on business performance. 200, 83-102 (2018)

[9] A. Ghobadian, I. Talavera, A. Bhattacharya, V. Kumar, J.A. Garza-Reyes, N. O'Regan, Examining legitimatisation of additive manufacturing in the interplay between innovation, lean manufacturing and sustainability. 2018

[10] L.S. Dalenogare, G.B. Benitez, N. F. Ayala, A.G. Frank, The expected contribution of Industry 4.0 technologies for industrial performance, 204, 383-394 (2018)

[11] A.G.Frank, L.S. Dalenogare, N.F. Ayal, Industry 4.0 technologies: Implementation patterns in manufacturing companies, 210, 15-26 (2019)

[12] M. Rossini, F. Costa, G. L. Tortorella, A. Portioli-Staudacher, The interrelation between Industry 4.0 and lean production: an empirical study on European manufacturers, 102, 3963-76 (2019)

[13] A. Ancarani, C. Di Mauro, F. Mascali, Backshoring strategy and the adoption of Industry 4.0: Evidence from Europe. 54, 360-371 (2019)

[14] E.A. Telegina, S.V. Eremin, P.B. Katuha, V.V. Bessel, I.I. Salahov, R.D. Kanayama, E.R. Sultanov, Transformation of energy markets: a new stage of technological development of the world energy. Oil, gas and business, 10, 43-52 (2017)

[15] U. Dombrowski, D. Ebentreich, P. Krenkel, Impact analyses of lean production systems. 57, $607-$ 612 (2016) 